\title{
Physical Properties of Wood from Steamed Eucalyptus grandis Logs
}

\author{
Paula Lúcia Martins Rodrigues ${ }^{1}$, Elias Taylor Durgante Severo ${ }^{1}$, \\ Fred Willians Calonego ${ }^{1}$, Melany Maria Alonso Pelozzi ${ }^{1}$, \\ João Vicente de Figueiredo Latorraca ${ }^{2}$
}

${ }^{1}$ Departamento de Ciências Florestais, Universidade Estadual Paulista - UNESP, Botucatu/SP, Brazil ${ }^{2}$ Departamento de Produtos Florestais, Universidade Federal Rural do Rio de Janeiro - UFRRJ, Seropédica/RJ, Brazil

\begin{abstract}
This study aimed to evaluate the effect of log steaming on the physical properties of Eucalyptus grandis Hill ex Maiden wood. Logs with diameters between 20 and $25 \mathrm{~cm}$ and length of $2.9 \mathrm{~m}$ were studied. Half the logs were maintained in their original condition, and the other half were steamed at $90{ }^{\circ} \mathrm{C}$ for 20 hours. Later, the logs were sawn into flat boards, and samples were removed to determine the physical properties of the wood. The results showed that log steaming caused a significant decreases of: (1) $6.38 \%$ and $7.98 \%$ in the respective basic and oven dried density; and (2) $7.20 \%, 7.80 \%, 5.13 \%$, and $8.56 \%$ in the volumetric, tangential, radial, and axial linear swelling of wood.
\end{abstract}

Keywords: steaming, maximum swelling, wood density. 


\section{INTRODUCTION}

Several defects are caused in eucalyptus wood during processing. These defects result in great yield losses and, consequently, make the use of eucalyptus for sawn wood impracticable (Touza Vásquez, 2001; Calonego et al., 2010; Severo et al., 2010). Techniques that have been used to relieve the tensions arising from growth stress include heating the logs in water or applying saturated steam (Skolmen, 1967; Severo \& Tomaselli, 2000; Juodeikiene \& Minelga, 2003; Calonego \& Severo, 2005; Rocha, 2011; Tan et al., 2011; Pellozzi et al., 2014).

Steaming wood is a technique applied for a variety of purposes, including to change color, reduce growth stress levels as already noted, improve dimensional stability, increase permeability, reduce initial moisture content, increase drying rate, and reduce the moisture gradient and drying defects (Simpson, 1975; Weik et al., 1984; Rowell, 1999; Zhang \& Cai, 2008; Calonego et al., 2010; Severo et al., 2010; Pellozzi et al., 2014).

Studies have shown approximately a $50 \%$ reduction in growth stress in Eucalyptus saligna logs after 24 hours of treatment in hot water (Skolmen, 1967), significant reductions of the length and width of cracks (44 and 53\%, respectively) in Eucalyptus dunnii after 20 hours of steaming (Severo \& Tomaselli, 2000) and a reduction in the length and width of cracks (about 34 and 48\%, respectively) in Eucalyptus grandis logs after 20 hours of steaming at $90{ }^{\circ} \mathrm{C}$ (Calonego \& Severo, 2005). The board's cracks were smallest in the Hevea brasiliensis logs that reached the glass transition temperature $\operatorname{logs}$ when steamed for $36 \mathrm{~h}$ at a temperature of $54^{\circ} \mathrm{C}, 75^{\circ} \mathrm{C}$ and $92^{\circ} \mathrm{C}$ (Pellozzi et al., 2014).

However, Yilgor et al. (2001) showed that the steaming of Fagus orientalis logs at $80^{\circ} \mathrm{C}$, for 100 hours caused decreases in basic density. Tan et al. (2011) reported that steaming Eucalyptus camaldulensis logs caused decreases of up to $12.87 \%$ in the volumetric, tangential and radial swellings when compared with the values observed for untreated wood.

Pinewood steamed for $24 \mathrm{~h}$ at $60{ }^{\circ} \mathrm{C}$ presented a decrease of up to $3.87 \%$ in the radial and tangential shrinkages. When the pinewood was steamed at $120^{\circ} \mathrm{C}$ there was a reduction of up to $9.68 \%$ in the respective physical properties (Juodeikiene \& Minelga, 2003).

Stamm (1956), Haygreen et al. (2003) and Green et al. (1999) reported that heating wood at high temperatures caused the degradation of some of its chemical components. Hemicellulose is the most thermally unstable component and degrades easily (Stamm, 1956). In high humidity, wood is degraded by acid hydrolysis. When acid concentration is high degradation becomes significant even at temperatures below $100{ }^{\circ} \mathrm{C}$ (Fengel \&Wegener, 1984).

According to Rocha (2011), steaming logs at $90{ }^{\circ} \mathrm{C}$ changes the chemical properties of Eucalyptus grandis wood. Thermal treatment promoted an increase in the solubility at $1 \% \mathrm{NaOH}$ and total extractives contents; and a decrease in the respective holocellulose and cellulose contents.

Yilgor et al. (2001) showed that steaming Fagus orientalis logs at $80^{\circ} \mathrm{C}$, for 100 hours caused degradation of hemicellulose and weight loss. According to the authors, thermal treatment caused a decrease in arabinose, galactose, rhamnose and mannose content.

This study aimed to evaluate the effect of log steaming on the physical properties of Eucalyptus grandis Hill ex Maiden wood.

\section{MATERIAL AND METHODS}

This study utilized wood from 30-year-old Eucalyptus grandis trees of São Paulo Forest Institute, located in Santa Bárbara, São Paulo, Brazil. The reforestation (2.2 ha) presents initial spacing of $2.0 \mathrm{~m} \mathrm{x} 3.0 \mathrm{~m}$ and has undergone three selective thinnings prior to timber harvesting. After felling, the trees were sectioned into 2.9 m logs.

Steaming logs was used to relieve growth stress. This treatment was applied to half-logs with diameters of 20 to $25 \mathrm{~cm}$. The other half of the log was kept as a control. The logs were steamed for 20 hours at a temperature of $90^{\circ} \mathrm{C}$ with $100 \%$ relative humidity as performed by Severo \& Tomaselli (2000), Calonego \& Severo (2005), Calonego et al. (2010) and Severo et al. (2010). The steamer was equipped with an electric boiler with $30 \mathrm{kgfh}^{-1}$ of steam-producing capacity and an operating pressure of $8 \mathrm{kgf} \mathrm{cm}^{-2}$.

Later, the untreated and steamed logs were cut into flat sawn boards. The boards that contained the pith were cut into $28-\mathrm{mm}$ thick pieces for this study. Subsequently, all the boards were dried by up to $10.0 \%$ of their moisture content in a dry kiln with a capacity of approximately $2.5 \mathrm{~m}^{3}$ of wood. 
Samples free of knots and defects were extracted from each board (untreated and steamed wood) according to the standards presented in ABNT NBR-7190 (ABNT, 1997) for physical characterization (oven dried density, basic density, equilibrium moisture content, and volumetric, tangential, radial and axial maximal swellings) of the wood. The samples were cut to create wood perfectly oriented in relation to growth rings, measuring 30 by 20 by $50 \mathrm{~mm}$ in respective radial, tangential and longitudinal direction.

Although the ABNT NBR-7190 (ABNT, 1997) standard shows that the necessary number of samples to characterise the physical properties of wood is six, fifty-three samples obtained from four boards from each treatment were used in this study (untreated and steamed woods)

The untreated and steamed wood samples were placed in an oven at $103 \pm 2{ }^{\circ} \mathrm{C}$, and were maintained in this condition until they reached $0 \%$ moisture content.

Subsequently, the samples were placed in a climatic chamber in the Laboratory of Wood Drying and Preservation in the Department of Forest Science, FCA - UNESP, Botucatu, SP, Brazil. The climatic chamber was adjusted at $21^{\circ} \mathrm{C}$ and $65 \%$ relative humidity until the samples reached the equilibrium moisture content. Later, the samples were submerged in water until the cell walls were completely saturated.

After each hygroscopic phase, the samples were weighed, and their dimensions were measured using a 0.01 -g precision scale and a $0.01-\mathrm{mm}$ accuracy micrometer.

For the evaluation of physical properties (basic density, oven dried density, equilibrium moisture content and maximum swelling), an analysis of variance with 95\% probability was performed, taking into account the thermal treatment.

\section{RESULTS AND DISCUSSION}

The basic density and oven dried density and equilibrium moisture content of untreated and steamed Eucalyptus grandis wood are shown in Table 1.

Steaming caused significant decreases of $6.38 \%$ and $7.98 \%$ in the basic density and oven dried density, respectively. The results are similar to those found by Yilgor et al. (2001) which showed that the steaming of Fagus orientalis logs at $80^{\circ} \mathrm{C}$, for 100 hours caused decreases of $0.638 \mathrm{~g} \mathrm{~cm}^{-3}$ to $0.620 \mathrm{~g} \mathrm{~cm}^{-3}$ in basic wood density.

The reductions in the wood densities have been explained by several authors, who reported that steaming wood causes degradation of some of its chemical compounds, mainly hemicelluloses (Stamm, 1956; Fengel \& Wegener, 1984; Haygreen et al., 2003; Rocha, 2011), which results in a loss of weight from the wood (Green et al., 1999; Yilgor et al., 2001).

The equilibrium moisture content was $9.4 \%$ for untreated and steamed wood when acclimatized at $21 \pm 1{ }^{\circ} \mathrm{C}$ and $65 \pm 5 \% \mathrm{RH}$. It is noted that the equilibrium moisture content of the material was not $12 \%$ due to the phenomenon known as hysteresis. The wood behaves differently when in contact with water than when it is removed. This implies that the adsorption curve is fitted below to the desorption curve (Simpson \& TenWolde, 1999; Haygreen et al., 2003).

In addition, the effect of log steaming on the dimensional instability of Eucalyptus grandis wood can be seen in detail in Table 2 .

In Table 2, it can be seen that the volumetric, tangential, radial, and axial maximal swellings of untreated E. grandis wood were 29.01\%, 17.29\%, $9.67 \%$, and $0.29 \%$, respectively. The results are similar to those found by Simpson \& TenWolde (1999) and Tan et al. (2011).

Table 1. Effect of log steaming on the densities of Eucalyptus grandis wood.

\begin{tabular}{|c|c|c|c|c|c|c|c|}
\hline \multirow[t]{2}{*}{ Treatment } & \multirow[t]{2}{*}{$\mathbf{N}$} & \multicolumn{2}{|c|}{$\begin{array}{l}\text { Oven dried density } \\
\left(\mathrm{g} \mathrm{cm}^{-3}\right)\end{array}$} & \multicolumn{2}{|c|}{$\begin{array}{c}\text { Basic density } \\
\left(\mathrm{g} \mathrm{cm}^{-3}\right)\end{array}$} & \multicolumn{2}{|c|}{$\begin{array}{c}\text { Equilibrium Moisture Content } \\
\text { at } 21^{\circ} \mathrm{C} \text { and } 65 \% \text { HR (\%) }\end{array}$} \\
\hline & & cv & Average & cv & Average & cV & Average \\
\hline Untreated & 23 & 10.2 & 0.789 & 8.3 & 0.611 & 0.7 & 9.4 \\
\hline Steamed & 30 & 7.6 & 0.726 & 6.3 & 0.572 & 1.6 & 9.4 \\
\hline Decrease (\%) & & \multicolumn{2}{|c|}{$7.98^{*}$} & \multicolumn{2}{|c|}{$6.38^{*}$} & \multicolumn{2}{|c|}{$0.00^{\mathrm{NS}}$} \\
\hline
\end{tabular}

Where: $\mathrm{N}$ - repeated number; cv - coefficient of variation; ${ }^{*}$ significant difference of by $\mathrm{F}$ test at $95 \%$ probability; ${ }^{\mathrm{NS}}$ non-significant difference. 
Table 2. Effect of log steaming on the dimensional instability of Eucalyptus grandis wood.

\begin{tabular}{|c|c|c|c|c|c|c|c|c|c|}
\hline \multirow[t]{2}{*}{ Treatment } & \multirow[t]{2}{*}{$\mathbf{N}$} & \multicolumn{2}{|c|}{ Volumetric (\%) } & \multicolumn{2}{|c|}{$\begin{array}{c}\text { Tangential linear } \\
(\%)\end{array}$} & \multicolumn{2}{|c|}{ Radial linear (\%) } & \multicolumn{2}{|c|}{ Axial linear (\%) } \\
\hline & & cv & Average & CV & Average & cv & Average & cV & Average \\
\hline Untreated & 23 & 10.2 & 29.01 & 11.9 & 17.29 & 9.6 & 9.67 & 17.9 & 0.29 \\
\hline Steamed & 30 & 12.1 & 26.92 & 15.3 & 15.94 & 8.4 & 9.17 & 14.5 & 0.27 \\
\hline Decrease (\%) & & \multicolumn{2}{|c|}{$7.20^{*}$} & \multicolumn{2}{|c|}{$7.80^{*}$} & \multicolumn{2}{|c|}{$5.13^{*}$} & \multicolumn{2}{|c|}{$8.56^{\mathrm{NS}}$} \\
\hline
\end{tabular}

Where: N - repeated number; cv - coefficient of variation; ${ }^{*}$ significant difference by F test at $95 \%$ probability; ${ }^{N}$ no significant difference.

The present study demonstrates that steaming Eucalyptus grandis wood caused reductions of 7.20\%, $7.80 \%, 5.13 \%$, and $8.56 \%$ in volumetric, tangential, radial and axial swelling when compared with untreated Eucalyptus grandis wood.

The results presented in this study are similar to those found by Tan et al. (2011) which showed that steaming Eucalyptus camaldulensis logs caused a decrease of $12.87 \%$, $6.69 \%$ and $10.47 \%$ in the respective volumetric, tangential and radial swellings when compared with the values found for untreated wood. Similar outcomes were also reported by Juodeikiene \& Minelga (2003) who showed that pinewood steamed for $24 \mathrm{~h}$ at $120^{\circ} \mathrm{C}$ presented a reduction of $9.68 \%$ and $4.34 \%$ in respective radial and tangential shrinkage.

The increases in dimensional stability and decreases in hygroscopicity of wood can be explained by Stamm (1956), Fengel \& Wegener (1984), Green et al. (1999), Rowell (1999), Haygreen et al (2003) and Yilgor et al. (2001), who reported that steaming wood causes degradation of some of its chemical compounds, principally the hemicelluloses and amorphous region of cellulose, thereby contributing to the increase in the degree of crystallinity of this polymer.

The characterization of the chemical composition of Eucalyptus grandis wood used in this study was established by Rocha (2011). According to the author, steaming the timber at $90^{\circ} \mathrm{C}$ changes the chemical properties of the wood. This thermal treatment promoted an increase of $5.1 \%$ and $4.8 \%$ in the solubility at $1 \% \mathrm{NaOH}$ and total extractive contents; and a decrease of $3.1 \%$ and $5.1 \%$ in the respective holocellulose and cellulose contents.

\section{CONCLUSIONS}

In verifying the effects of log steaming on the physical properties of E. grandis, it was concluded that there was a significant reduction in basic density and oven dried density. Additionally, log steaming led to reductions in the volumetric, tangential, radial, and axial linear swellings of wood.

\section{SUBMISSION STATUS}

Received: 13 feb., 2016

Accepted: 24 nov., 2016

\section{CORRESPONDENCE TO}

\section{Fred Willians Calonego}

Departamento de Ciências Florestais, Universidade Estadual Paulista - UNESP, Fazenda Experimental Lageado, s/n, CEP 18610-307, Botucatu, SP, Brazil e-mail: fwcalonego@ig.com.br

\section{REFERENCES}

Associação Brasileira de Normas Técnicas - ABNT. NBR 7190: Ações nas estruturas, propriedades da madeira $e$ dimensionamento nos estados limites de utilização. Rio de Janeiro: ABNT, 1997.

Calonego FW, Severo ETD. Efeito da vaporização de toras na redução dos defeitos associados a tensões de crescimento de Eucalyptus grandis. Ciência Florestal 2005; 15(4): 341-440. http://dx.doi.org/10.5902/198050981880.

Calonego FW, Severo ETD, Cunha AR, Gaia D. Use of glass transition temperature for stabilization of board's cracks of Eucalyptus grandis. Anais da Academia Brasileira de Ciencias 2010; 83(3): 1-7. PMid:21562706.

Fengel D, Wegener G. Wood chemistry: ultrastructure reactions water. New York: Walter de Gruyter Press, 1984.

Green DW, Winandy JE, Kretschmann DE. Mechanical properties of wood. In: Forest Products Laboratory. Wood handbook: wood as an engineering material. Washington: USDA, 1999. 
Haygreen JG, Bowyer JL, Shmulsky R. Forest products and wood science: an introduction. Iowa: Iowa State Press/ AMES, 2003.

Juodeikiene I, Minelga D. The influence of heating on wood hygroscopicyty and dimensional stability. Materials Science 2003; 9(2): 209-212.

Pellozzi MMA, Severo ETD, Rodrigues PLM, Calonego FW. Temperature charts of Hevea brasiliensis during log steaming and its effect on the board cracks. European Journal of Wood and Wood Products 2014; 72(1): 123-128. http://dx.doi.org/10.1007/s00107-013-0759-3.

Rocha CD. Efeito da vaporização na madeira de Eucalyptus grandis sobre as suas propriedades químicas e resistência natural a fungos e cupins [dissertação]. Botucatu: Faculdade de Ciências Agronômicas, Universidade Estadual Paulista; 2011.

Rowell RM. Specialty treatments. In: Forest Products Laboratory. Wood handbook: wood as an engineering material. Washington: USDA, 1999.

Severo ETD, Calonego FW, Matos CAO. Lumber quality of Eucalyptus grandis as a function of diametral position and log steaming. Bioresource Technology 2010; 101(7): 2545-2548. PMid:20007016. http://dx.doi.org/10.1016/j. biortech.2009.11.083.

Severo ETD, Tomaselli I. Vaporização no alívio das tensões de crescimento em toras de Eucalyptus dunnii de duas procedências. Sciencia Agraria 2000; 1(1-2): 29-32. http://dx.doi.org/10.5380/rsa.v1i1.964.
Simpson W, TenWolde A. Physical properties and moisture relations of wood. In: Forest Products Laboratory. Wood handbook: wood as an engineering material. Washington: USDA, 1999.

Simpson WT. Effect of steaming on the drying rate of several species of wood. Wood Science 1975; 7: 247-255.

Skolmen RG. Heating logs to relieve growth stresses. Forest Products Journal 1967; 17: 41-42.

Stamm AJ. Thermal degradation of wood and cellulose. Industrial \& Engineering Chemistry 1956; 48(3): 413-416. http://dx.doi.org/10.1021/ie51398a022.

Tan H, Ay N, Bakir D, Tufan M, Peke H. Influence of steaming on the some physical properties of Eucalyptus (Eucalyptus camaldulensis dehn.) wood. Artvin Çoruh Üniversitesi Orman Fakültesi Dergisi 2011; 12: 49-56.

Touza Vásquez MC. Proyecto de investigación sobre sistemas de aserrado adecuados para processar Eucalyptus globulus com tensiones de crecimiento. Revista CISMadera 2001; 6: 8-37.

Weik BB, Wengert EM, Schoreder J, Brisbin R. Practical drying techniques for yellow-poplar S-D-R fliches. Forest Products Journal 1984; 34: 39-44.

Yilgor N, Unsal O, Kartal SN. Physical, mechanical, and. chemical properties of beech wood. Forest Products Journal 2001; 51(11/12): 89-93.

Zhang Y, Cai L. Impact of heating speed on permeability of sub-alpine fir. Wood Science and Technology 2008; 42(3): 241-250. http://dx.doi.org/10.1007/s00226-007-0172-3. 